\title{
Meningkatkan Motivasi dan Hasil Belajar IPA dengan Menggunakan Model Pembelajaran Project Based Learning (PjBL)
}

\author{
Elisabet $^{1 *}$, Stefanus C. Relmasira ${ }^{2}$, Agustina Tyas Asri Hardini ${ }^{3}$ \\ 1,2,3 Pendidikan Guru Sekolah Dasar, Fakultas Keguruan dan Ilmu Pendidikan, Universitas Kristen Satya Wacana, Salatiga, Indonesia
}

\begin{tabular}{l} 
A R T I C L E I N F O \\
\hline Article history: \\
Received 20 May 2019 \\
Received in revised form \\
10 June 2019 \\
Accepted 30 July 2019 \\
Available online 28 \\
August 2019 \\
\hline
\end{tabular}

Kata Kunci:

motivasi, hasil belajar, Project Based Learning

Keywords:

Motivation, Result of

Learning, Project Based

Learning

\begin{abstract}
A B S T R A K
Penilitian ini bertujuan untuk meningkatkan motivasi dan hasil belajar IPA dengan menggunakan model pembelajaran Project Based Learning (PjBL) pada siswa kelas V SD Negeri Gendongan 03 Salatiga 2018/2019. Penelitian ini merupakan jenis penelitian PTK yang dilaksanakan dalam dua siklus dengan menggunakan model spiral oleh C. Kemmis dan MC. Taggart. Subjek penelitian adalah siswa kelas V SD Negeri Gendongan 03 Salatiga dengan jumlah 37 siswa. Teknik pengumpulan data pada penelitian ini menggunakan metode deskriftif komparatif dengan membandingkan hasil dari pra siklus sampai siklus II. Pada pra siklus persentase motivasi belajar siswa terdapat $44 \%$ dalam kategori sedang, sebanyak $56 \%$ dalam kategori rendah, kemudian secara bertahap meningkat menjadi $30 \%$ dalam kategori tinggi, 54\% dalam kategori sedang, dan $16 \%$ dalam kategori rendah pada siklus I. Sedangkan pada siklus II meningkat sebanyak $83 \%$ dalam kategori tinggi, $11 \%$ dalam kategori sedang dan $5 \%$ dalam kategori rendah. Meningkatnya motivasi siswa dalam belajar juga berdampak pada hasil belajar siswa, dimana pada pra siklus memperoleh persentase $40 \%$, dan meningkat secara bertahap dengan persentase $62 \%$ pada siklus I, sedangkan untuk siklus II meningkat dengan persentase sebanyak $81 \%$. Dapat disimpulkan bahwa dengan menggunakan model Project Based Learning mampu membantu siswa dalam meningkatkan motivasi dan hasil belajar pada mata pelajaran IPA.
\end{abstract}

A B S T R A C T

This study to improving motivation and the result of learning science using a Project Based Learning model on grade V student in elementary school Gendongan 03 Salatiga 2018/2019. This research is a type of class action research implemented in two cycles by using a spiral model by $C$. Kemmis and MC. Taggart. The research subject is grade $V$ student in elementary school Gendongan 03 Salatiga with 37 student. The data collection techniques of this research use a comative descriptive method by comparing the result from pre cycle to cycle II. In the pre cycle of percentages the motivation for student study is $44 \%$ in the medium category, $56 \%$ in the low category, then gradually increase to $30 \%$ in the high category, $54 \%$ in the medium category, and $16 \%$ in the low category of cycle I. As for cycle II increasing into the $83 \%$ in the high category, $11 \%$ in the medium category and $5 \%$ in the low category. The increasing motivation of students in learning also impacted on student study results, in the pre cycle gain a percentage of $40 \%$ and gradually increase to as much $81 \%$. It could be deduced that by using project Based Learning being able to help students in improving motivation and the result of learning the science. 


\section{Pendahuluan}

Peraturan pemerintah Republik Indonesia nomor 19 tahun 2005 tentang standar nasional pendidikan, memuat tentang standar proses, dinyatakan bahwa proses pembelajaran pada satuan pendidikan diselenggarakan secara interaktif, inspiratif, menyenangkan, menantang, dan memotivasi peserta didik dalam belajar untuk membangun minat dan pengetahuan. Dapat diketetahui bahwa siswa bukan hanya menguasai materi pelajaran saja untuk mengetahui intelektualnya, melainkan bagaimana pengetahuan yang didapatkan oleh siswa itu dapat membuat siswa menjadi termotivasi dalam perilaku yang harus ditampilkan dikehidupan nyata untuk meningkatkan berpikir kritis siswa dalam menyelesaikan sebuah masalah.

Namun, Hasil observasi pada kegiatan tematik muatan mata belajaran IPA kelas V SDN Gendongan 03 Salatiga tahun ajaran 2018/2019 diketahui penyebab adanya ketidak tercapaian ketuntasan minimal dari beberapa siswa, hal ini dapat diketahui dari hasil kondisi awal terdapat 22 siswa dari 37 siswa masih dibawah KKM. Banyaknya nilai siswa yang masih dibawah KKM dikarenakan kurangnya konsentrasi yang terjadi karena siswa sering melamun pada saat guru menerangkan atau menjelaskan, dan pada saat guru meminta siswa untuk mengerjakan soal siswa tidak membaca dengan benar perintah soal dan pertanyaan soal dengan benar. Sehingga diperlukan strategi pembelajaran yang lebih efektif untuk diterapkan dalam proses belajar mengajar.

Permasalahan diatas dapat diketahui bahwa siswa kurangnya motivasi dalam belajar. Oleh karena itu, diperlukanlah sebuah solusi untuk meningkatkan motivasi belajar siswa. Motivasi merupakan sebuah topik yang berkaitan erat dengan pembelajaran. Motivasi ialah proses mendorong dan mempertahankan tujuan dengan mengarahkan perilaku (Schunk, 2012:475). Menurut Robbins (2001), motivasi memiliki pengertian bahwa satu proses yang menghasilkan suatu intensitas, arah, dan ketekunan dalam usaha untuk mencapai suatu tujuan. Motivasi mengandung tiga komponen pokok, yaitu kebutuhan, tujuan dan dorongan. Kebutuhan terjadi bila individu merasa ada ketidakseimbangan antara yang ia miliki dengan apa yang ia harapkan. Dorongan merupakan kekuatan mental untuk melakukan kegiatan rangka memenuhi harapan atau pencapaian tujuan (A. B. Susilo, 2012). Dapat diketahui persamaan dari ketiga teori tersebut bahwa motivasi merupakan sebuah dorongan bagi siswa untuk mencapai suatu tujuan. Tujuan tersebut dapat membangkitkan semangat belajar siswa, dan dapat menumbuhkan rasa percaya diri, sehingga siswa mendapatkan sebuah dorongan untuk belajar dengan baik.

Motivasi dan hasil belajar siswa terutama pada tematik muatan mata pelajaran IPA kelas V semester I. Dari hasil observasi yang dilakukan, ada beberapa siswa yang memiliki tingkat motivasi yang masih tergolong rendah, hal ini juga berpengaruh dengan hasil belajarnya. Penyebab ketidak tercapainya ketuntasan dari beberapa siswa dikarenakan siswa kurang memahami soal evaluasi yang diberikan oleh guru, dan siswa juga terlihat tidak konsentrasi dalam belajar yang mengakibatkan siswa sering melamun pada saat guru menerangkan dan pada saat guru meminta siswa untuk mengerjakan soal. Berdasarkan hasil observasi yang dilakukan di SDN Gendongan 03 Salatiga dapat diketahui ketika peneliti melihat langsung kondisi dikelas pada saat melakukan observasi. Dan peneliti juga melakukan sebuah wawancara dari guru kelas V dan siswa Kelas V, dalam wawancara tersebut guru kelas V mengatakan bahwa masih ada beberapa siswa yang memiliki kemampuan berpikir kritis rendah, sehingga pada saat guru memberikan pertanyaan terdapat beberapa siswa masih kurang aktif dalam bertanya atau menjawab pertanyaan, dan guru kelas $\mathrm{V}$ juga mengatakan bahwa minimnya alat peraga yang ada disekolah sangat menghambat proses pembelajaran. Sedangkan saat wawancara dengan beberapa siswa, dapat diketahui bahwa siswa tidak berani bertanya dikarenakan siswa takut dan segan untuk bertanya kepada guru, dan alasan siswa tidak menjawab pertanyaan yang diberikan guru dikarenakan siswa takut jawabannya salah, dan tidak percaya diri untuk menjawab pertanyaan dengan jawaban sendiri.

Menurut Afriana (2016) Model PjBL adalah sebuah model pembelajaran yang menggunakan proyek (kegiatan) sebagai inti pembelajaran. Pembelajaran PjBL terbukti dapat meningkatkan kreativitas siswa. Menurut Rais (2010) Project Based Learning merupakan sebuah model pembelajaran yang sudah banyak dikembangkan di negara-negara maju seperti Amerika Serikat. Jika diterjemahkan dalam bahasa Indonesia, Project Based Learning (PBL) bermakna sebagai pembelajaran berbasis proyek. Dengan sudut pandang yang sedikit berbeda Baron (1998, p.271) seperti dikutip Lindawati, Fatmariyanti, dan Maftukhin, 2013, p.43) berpendapat bahwa Project Based Learning adalah suatu pendekatan pembelajaran yang membenturkan siswa kepada masalahmasalah praktis melalui stimulus dalam belajar. Peranan guru sangat penting dalam memberikan stimulus-stimulus agar siswa dapat melakukan pembelajaran secara mandiri, menemukan pemahamannya sendiri dan mengembangkan kreatifitasnya secara kolaboratif. Menurut Wajdi (2017) Project Based Learning memberikan pengalaman belajar yang detail, rinci, menantang, dan dalam jangka waktu yang lebih panjang dengan target terselesaikannya proyek yang menghasilkan sebuah produk, karya siswa yang memuaskan. Menurut Waras (2008) Project 
Based Learning merupakan proyek yang memfokuskan pada pengembangan produk atau unjuk kerja (Performance), siswa melakukan kegiatan mengorganisasikan kegiatan belajar kelompok, melakukan pengkajian atau penelitian, memecahkan masalah, dan mensistesis informasi. Project Based Learning merupakan pendekatan pembelajaran yang memberikan kebebasan kepada peserta didik untuk merencanakan aktivitas belajar, melaksanakan proyek secara kolaboratif, dan pada akhirnya menghasilkan produk kerja yang dapat dipresentasikan kepada orang lain (Nurohman, 2007). Model pembelajaran Project Based Learning merupakan salah satu inovasi dalam pembelajaran yang dapat digunakan, karena PjBL bertujuan melatih siswa dalam berpikir kritis, kreatif, dan rasional, aktif berkolaborasi dan berkomunikasi, dan nyata terhadap siswa (Saputra, 2013). Project Based Learning merupakan model yang menghasilkan sebuah proyek, dalam pembuatan proyek siswa akan membuat sebuah produk, dimana dalam pembuatan produk dapat memberikan kebebasan kepada siswa untuk membuat produk yang akan dipresentasikan kepada teman sekelas. Model pembelejan Project Based Learning (PjBL) ini dapat membantu siswa untuk melatih berpikir kritis, dan kreatif untuk membuat produk yang berkualitas. Harapannya ketika belajar mengajar terlaksana dengan baik maka motivasi juga meningkat disertai dengan hasil belajar siswa. Menurut Sani (2013) Peran guru dalam proses ini adalah memacu siswa untuk berpikir dalam memberikan solusi atau tanggapan terhadap permasalahan yang ada. Peserta didik diajak secara bertahap dan sistematis menggali, mengolah, dan menggodok masalah (dalam bentuk skenario) yang diberikan kepada mereka. Masalah dalam skenario diharapkan mampu memicu dan memacu kemampuan berfikir analitis, aktif, sekaligus melakukan pembelajaran secara kreatif (creatif learning), dan belajar bekerja sama (collaborative learning).

Hasil belajar merupakan prestasi belajar peserta didik secara keseluruhan, yang menjadi indikator kompetensi dasar dan derajat perubahan perilaku yang bersangkutan (Mulyasa, 2006). Ketiga ranah yang dimaksudkan oleh Bloom menurut Mediawati (2011:9):

1) Ranah Kognitif

Ranah kognitif yaitu kemampuan menyatakan kembali konsep atau prinsip-prinsip yang telah dipelajari dan kemampuan pengembangan keterampilan intelektual (knowledge) dalam berbagai tingkatan, yaitu: (a) Recall of data (Hapalan/C1); (b) Comprehension (Pemahaman/C2); (c) Apllication (Penerapan/C3); (d) Analysis (Analisis/C4); (e) Synthesis (Sintesis/C4); (f) Evaluation (Evaluasi/C6).

2) Ranah Afektif

Ranah afektif berkaitan dengan perkembangan emosional individu siswa seperti sikap (attitude), apresiasi (appreciation), minat, perhatian, penghargaan, proses internalisasi dan pembentukan karakter diri. Hasil belajar pada ranah afektif dapat di tunjukkan dengan adanya perubahan positif pada tingkah lau siswa, seperti perhatiannya terhadap pelajaran, disiplin, motivasi belajar, menghargai guru dan teman, kebiasaan beklajar dan hubungan sosial yang baik. Bloom membagi ranah afektif dalam lima kategori, yaitu: (a) Receiving (penerimaan); (b) Responding (Pemberian respon); (c) Valueing (Penilaian), Organization (Pengorganisasian); dan (e) Characterization (Karakterisasi).

3) Ranah Psikomotor

Ranah psikomotor berhubungan dengan kemampuan garak siswa atau manipulasi yang bukan disebabkan oleh kematangan biologis. Kemampuan gerak atau manipulasi tersebut akan terkendali oleh kematangan psikologis siswa itu sendiri.

Berdasarkan definisi hasil belajar menurut para ahli tersebut, maka yang dimaksud dengan hasil belajar dalam penelitian adalah hasil akhir dari proses kegiatan belajar siswa dari seluruh kegiatan siswa dalam mengikuti pembelajaran di kelas dan menerima suatu pelajaran untuk mencapai kompetensi yang berupa aspek kognitif yang diungkapkan dengan menggunakan suatu alat penilaian yaitu tes evaluasi dengan hasil yang dinyatakan dalam bentuk nilai, aspek afektif yang menunjukkan sikap siswa dalam mengikuti pembelajaran, dan aspek psikomotorik yang menunjukkan keterampilan dan kemampuan bertindak siswa dalam mengikuti pembelajaran.

\section{Metode}

Penelitian ini merupakan Penelitian Tindakan Kelas (PTK) penelitian ini dilakukan dalam kelas untuk memecahkan suatu masalah yang dihadapi oleh guru dalam proses belajar mengajar di kelas, hal ini untuk memperbaiki mutu dan hasil pembelajaran pada peserta didik. Sebagai upaya untuk menerapkan di berbagai teknik, metode atau strategi dalam pembelajaran secara efektif dan efisien. Prosedur penelitian ini mengacu pada Kemmis dan Mc Taggart (Tampubolon, 2014:27) terdapat empat tahap rencana tindakan, meliputi: perencanaan (planning), pelaksanaan (acting), dan pengamatan (observasi), refleksi (reflecting).

Penelitian ini dilaksanakan dalam 2 siklus, dimana masing-masing siklus terdiri dari 3 pertemuan, dari setiap pertemuan siklus I dan II mengalami peningkatan secara bertahap, untuk pertemuan pertama 
siswa diminta untuk mencari informasi tentang materi yang akan diajarkan, dalam pertemuan ke 2 siswa difokuskan untuk membuat proyek, sedangkan untuk pertemuan ke 3 digunakan sebagai evaluasi. Subyek penelitian ini adalah siswa kelas V SDN Gendongan 03 yang berjumlah 37 siswa, diantaranya 18 siswa perempuan dan 19 siswa laki-laki. Penelitian memiliki 2 variabel, variabel bebas dimana varibel bebas ini adalah model pembelajaran Project Based Learning (PjBL), sedangkan variabel terikat merupakan motivasi dan hasil belajar IPA.

Teknik pengumpulan data dalam penelitian ini menggunakan 1) Tes merupakan salah satu cara untuk memulai respon seseorang terhadap pertanyaan yang ada. Teknik tes peneliti ini menggunakan tes tertulis dengan bentuk pilihan ganda, isian, dan uraian. 2) Tugas Kelompok merupakan tugas yang diberikan secara kelompok. Keunggulan tugas kelompok ini dapat membantu siswa untuk memecahkan masalah dengan cara saling bertukar pendapat, dan saling membantu satu sama lain. 3) Observasi, Observasi dilakukan dengan sebuah proses pengamatan yang dilakukan oleh peneliti dengan mengambil sebuah objek yang diamati dalam sebuah penelitian.

\section{Hasil dan Pembahasan}

Sebelum melaksanakan pembelajaran siklus I dan siklus II, langkah yang pertama dilakukan adalah melakukan observasi dan wawancara untuk mengetahui apa saja permasalahan yang ada di dalam kelas $\mathrm{V}$ SDN Gendongan 03 Salatiga terutama pada mata pelajaran IPA. Dengan adanya tindakan observasi, peneliti dapat mengetahui situasi kelas dalam proses belajar sebelum dimenggunakan model pembelajaran Project Based Learning (PjBL). Dari hasil observasi tersebut bahwa ada beberapa siswa sering melamun pada saat guru menerangkan atau menjelaskan, dalam pembelajaran siswa kurang sepenuhmya memahami materi yang diberikan, dan pada saat guru meminta siswa untuk mengerjakan soal siswa tidak membaca dengan benar perintah soal dan pertanyaan soal dengan benar sehingga berdampak pada hasil belajar siswa.

Berdasarkan hasil penelitian dengan menggunakan model pembelajaran Project Based Learning (PjBL) dari siklus I sampai siklus II yang lalui peneliti mengalami peningkatan sesuai yang diharapkan. Dalam penelitian ini tahap akhir dalam setiap siklus, siswa diminta untuk mengerjakan soal evaluasi, dimana soal evaluasi ini dapat mengukur hasil belajar siswa terutama pada mata pelajaran IPA.

Berikut ini adalah hasil perbandingan dari hasil belajar pada pembelajaran tematik muatan mata pelajaran IPA dari sebelum tindakan sampai dengan berakhirnya siklus II.

Berdasarkan tabel 1 dibawah dapat diketahui bahwa peningkatan jumlah siswa yang masuk dalam kategori tinggi. Meningkatnya motivasi tersebut dilihat dari hasil observasi motivasi siswa dengan mengisi 6 aspek yang dijabarkan dalam 32 indikator.

Tabel 1. Hasil Komparatif Motivasi Siswa Pra Siklus, Siklus I, dan Siklus II

\begin{tabular}{cllccccccc}
\hline \multirow{2}{*}{ No. } & \multirow{2}{*}{$\begin{array}{c}\text { Jumlah } \\
\text { Skor }\end{array}$} & \multirow{2}{*}{ Kategori } & \multicolumn{2}{c}{ Pra Siklus } & \multicolumn{2}{c}{ Siklus I } & \multicolumn{2}{c}{ Siklus I } \\
\cline { 4 - 9 } & & F & $\mathbf{( \% )}$ & F & $\mathbf{( \% )}$ & F & $\mathbf{( \% )}$ \\
\hline 1 & $96-75,6$ & Tinggi & 0 & $0 \%$ & 11 & $30 \%$ & 30 & $83 \%$ \\
2 & $74,6-55,2$ & Sedang & 14 & $44 \%$ & 20 & $54 \%$ & 4 & $11 \%$ \\
3 & $54,2-32$ & Rendah & 21 & $56 \%$ & 6 & $16 \%$ & 2 & $5 \%$ \\
\hline \multicolumn{2}{l}{ Jumlah Siswa } & & $\mathbf{3 7}$ & $\mathbf{1 0 0} \%$ & $\mathbf{3 7}$ & $\mathbf{1 0 0 \%}$ & $\mathbf{3 7}$ & $\mathbf{1 0 0 \%}$ \\
\hline
\end{tabular}

Hasil dari Tabel 1, maka dapat diketahui bahwa ada peningkatan motivasi belajar dalam pra siklus, siklus I, dan siklus II. Hal tersebut terbukti sebelum adanya tindakan, terdapat 14 siswa atau $44 \%$ dalam kategori sedang. Setelah melakukan tindakan dengan menggunakan model Project Based Learning (PjBL) terutama pada mata pelajaran IPA pada siklus I dapat dilihat dari 37 siswa, terdapat 11 siswa atau $30 \%$ dengan kategori tinggi. Hal ini menunjukkan bahwa pada siklus I motivasi belajar siswa sudah meningkat walaupun belum mencapai hasil yang sudah ditentukan yaitu $80 \%$. Sedangkan pada siklus II terdapat 37 siswa, sebanyak 30 siswa atau $83 \%$ dalam kategori tinggi. Hasil tersebut dilihat dari lembar observasi yang berbentuk sebuah angket yang sudah diisi oleh masing-masing siswa. Maka dapat diketahui bahwa pada siklus II motivasi belajar siswa dapat dikatakan meningkat. 
Tabel 2. Hasil Komparatif Ketuntasan Hasil Belajar Mata Pelajaran IPA Pra Siklus, Siklus I, dan Siklus II

\begin{tabular}{cllcccccc}
\hline \multirow{2}{*}{ No. } & \multirow{2}{*}{ Kategori } & \multicolumn{2}{c}{ Pra Siklus } & \multicolumn{2}{c}{ Siklus I } & \multicolumn{2}{c}{ Sikus II } \\
\cline { 3 - 9 } & & $\mathbf{F}$ & $\mathbf{( \% )}$ & $\mathbf{F}$ & $\mathbf{( \% )}$ & F & $(\%)$ \\
\hline 1 & Tuntas $\geq 75$ & 15 & $40 \%$ & 23 & $62 \%$ & 30 & $81 \%$ \\
2 & Belum Tuntas $<75$ & 22 & $60 \%$ & 18 & $38 \%$ & 7 & $19 \%$ \\
\hline Rata-Rata & 57,72973 & 67,08108 & & 72,35135 & \\
\hline Nilai Tertinggi & 80 & \multicolumn{2}{c}{84} & & 85 & \\
\hline Nilai Terendah & 24 & & 36 & & 41 & \\
\hline
\end{tabular}

Perbandingan hasil analisis data terutama pada mata pelajaran IPA kelas V dapat dilihat dari Tabel 2 sebagai berikut: Berdasarkan tabel diatas dapat disimpulkam bahwa ada peningkatan hasil belajar, hal ini dapat dilihat dari beberapa siswa yang sudah mendapatkan nilai diatas KKM $\geq 75$. Hal ini terbukti sebelum melakukan tindakan, terdapat 15 siswa atau $40 \%$ hasil belajar siswa pada tematik muatan mata pelajaran IPA dalam kategori tuntas. Setelah dilaksanakan tindakan dengan menggunakan model pembelajaran Project Based Learning pada siklus I dapat dilihat sebanyak 23 siswa atau 62\% dengan nilai rata-rata 67,08. Sedangkan pada siklus II terdapat 30 siswa atau $81 \%$ dengan nilai rata-rata 72,35. Maka dapat disimpulkan bahwa tingkat keberhasilan yang dicapai sudah memenuhi standar indikator kinerja yang sudah ditetapkan dengan hasil $80 \%$.

Hasil penelitian yang dilaksanakan oleh peneliti pada siswa kelas V SDN Gendongan 03 Salatiga dengan menggunakan model Project Based Learning (PjBL) terjadi peningkatan mau dalam motivasi dan hasil belajar siswa terutama pada mata pelajaran IPA hal ini dapat diketahui dari hasil siklus I dan siklu II. Setelah dilakukan sebuah tindakan pada siklus I motivasi dan hasil belajar mengalami sebuah peningkatan. Hal ini dapat diketahui dari hasil angket dan hasil evaluasi yang diberikan oleh peneliti. Dalam proses pembelajaran siklus I motivasi siswa dalam belajar sudah mulai menonjol dan antusias dalam mengikuti pelajaran, siswa juga mulai terlihat aktif dalam berdiskusi untuk menghasilkan produk yang akan dibuat. Namun pada siklus I ini terdapat beberapa kendala, hal tersebut disebabkan karena ada beberapa siswa yang membuat kegaduhan saat mengerjakan proyek, hingga kelas tidak bisa terkontrol dengan baik. Maka dapat dikatakan dalam proses pelaksanaan pembelajaran masih terdapat kekurangan, untuk menutupi kekurangan-kekurangan tersebut peneliti berusaha memperbaiki proses pembelajaran selanjutnya di siklus II.

Pertemuan I, II dan III dalam siklus II sudah dianggap sangat baik, terutama pada motivasi dan hasil belajar. Meningkatkannya motivasi dan hasil belajar pada siklus II ini sudah mencapai indikator kinerja 80\%. Motivasi belajar siswa sangat tinggi, hal ini dapat dilihat dari cara siswa mendengarkan penjelasan materi, siswa juga sudah mulai percaya diri dalam bertanya, dan menjawab sebuah pertanyaan. Dalam pembuatan produk siswa sangat antusias, dapat dilihat saat siswa melakukan diskusi dengan teman sekelompoknya, dan menyusun rancangan apa saja bahan-bahan yang harus dibuat terdahulu, serta membagi pekerjaan pada anggota kelompoknya, dalam mempersentasikan hasil kerja kelompoknya siswa sudah menyampaikan dengan suara yang nyaring, dan siswa juga dapat menjawab pertanyaan yang diberikan dengan tutur bahasa yang baik dan dapat dipahami oleh kelompok lain. Untuk membangun suasana yang nyaman dalam pembuatan produk, peneliti meminta beberapa kelompok untuk membuat proyek diluar ruangan, dengan itu peneliti harus memperhatikan khusus agar proses pembelajaran berjalan dengan baik.

Dengan menggunakan model pembelajaran Project Based Learning (PjBL) terutama mata pelajaran IPA kelas V SDN Gendongan 03 membuat pembelajaran menjadi sangat menyenangkan dan antusias dalam proses belajar, hal ini dapat dilihat dari cara siswa mencari sebuah informasi tentang materi yang diberikan, dan siswa juga semakin aktif dalam pembelajaran. Model pembelajaran Project Based Learning (PjBL) sangat membantu dalam proses pembelajaran karena dapat membuat pengetahuan siswa lebih dalam, model ini dikemas untuk membuat sebuah proyek dan membentuk sebuah kelompok dimana siswa disini langsung mempraktekkan cara membuat produk yang akan dibuat. Model ini juga sangat membantu siswa dalam bersosialisasi, karena dengan adanya kerja kelompok siswa bisa berdiskusi dan mengeluarkan pendapat siswa untuk menghasilkan produk yang lebih baik. Selain berdiskusi dan mempraktekkan secara langsung membuat produk, siswa juga dilatih untuk berbicara didepan teman sekelasnya atau dilingkungan sekolah, sehingga pengalaman yang siswa alami semakin bertambah, dalam model ini siswa tidak hanya mencari informasi darisumber buku paket saja, tetapi dapat mencari informasi dari teman sekelas atau orang-orang yang berada diwilayah sekolah, siswa juga dapat belajar dan mendapatkan pengetahuan yang lebih luas dengan media yang bervariatif, seperti produk yang dibuat, video, PPT, dan kerja sama dalam sebuauh kelompok. Disetiap ada kelebihan, pasti ada 
kekuranganya, kekurangan dalam model ini dimana siswa tidak dapat terkontrol dengan baik, contohnya: Kegaduhan didalam kelas, ini sangat berpengaruh dalam pembuatan produk karena siswa tidak dapat konsentrasi atau tidak fokus dengan apa yang siswa buat.

Hasil penelitian ini mendukung dan memperkuat bebagai penelitian terdahulu anatara lain: Umi Faizah (2015, Ari Septiasih, Ngurah Japa, Wayan Arini (2016), Dyah kamayani, sumantri, sudana (2013), Purnomo, Mawarsari (2014), Rini Astuti (2015) maka dapat disimpulkan bahwa model pembelajaran Project Based Learning (PjBL) dapat meningkatkan motivasi dan hasil belajar siswa. Namun terdapat beberapa perbedaan dari setiap penelitian sebelumnya dengan penelitian ini, penelitian saat ini adalah meningkatkan motivasi dan hasil belajar IPA dengan menggunakan model pembelajaran Project Based Learning (PjBL) untuk kelas V SD. Penelitian ini bukan hanya meningkatkan aspek kognitifnya saja, melainkan aspek afektif dan psikomotorifnya juga ikut meningkat.

\section{Simpulan dan Saran}

Berdasarkan hasil penelitian tindakan kelas yang dilaksanakan pasa siswa kelas V SDN Gendongan 03 Salatiga semester I tahun ajaran 2018/2019, dengan judul meningkatkan motivasi dan hasil belajar IPA dengan menggunakan model pembelajaran Project Based Learning (PJBL) untuk siswa kelas V SD. Dengan menggunakan model ini dapat meningkatkan motivasi dan hasil belajar IPA, hal ini dapat dilihat dari 37 siswa hanya 7 siswa yang belum memenuhi kekuntasan KKM. meskipun masih ada 7 siswa yang belum tuntas akan tetapi nilai siswa setiap siklusnya selalu meningkat sehingga tidak terlalu jauh dari nilai KKM. Dalam penelitian ini terbukti bahwa hipotesis tindakan melalui model pembelajaran Project Based Learning (PjBL) dapat meningkatkan motivasi dan hasil belajar IPA kelas V SDN Gendongan 03 Salatiga pada semester I tahun ajaran 2018/2019. Dengan demikian penelitian ini sudah mencapai indikator kinerja sesuai yang ditetapkan oleh peneliti. Beradarkan hasil penelitian ini disarankan agar guru terutama pada mata pelajaran IPA dapat menggunakan model pembelajaran Project Based Learning (PjBL) sebagai salah satu alternatif model pembelajaran selanjutnya

\section{Daftar Rujukan}

Afriana, J., dan Fitriani, A. (2016). "Penerapan Project Based Learning Terintegrasi STEM Untuk Meningkatkan Literasi Sains Dan Kreativitas Siswa Ditinjau Dari Gender". Jurnal Inovasi Pendidikan IPA, 2(2): 202-212.

Astuti, R. (2015). Meningkatkan Kreativitas Siswa Dalam Pengolahan Limbah Menjadi Trash Fashion Melalui PjBL. Bioedukasi: Jurnal Pendidikan Biologi, 8(2), 37-41.

Hamdu, G., \& Agustina, L. (2011). Pengaruh motivasi belajar siswa terhadap prestasi belajar IPA di sekolah dasar. Jurnal penelitian pendidikan, 12(1), 90-96.

Kamayani, I. D., Sumantri, M., \& Sudana, D. N. (2013). PENGARUH MODEL PEMBELAJARAN PROJECT BASED LERNING BERBANTUAN MEDIA TIGA DIMENSI TERHADAP HASIL BELAJAR IPA DI SD GUGUS IX KECAMATAN BULELENG. MIMBAR PGSD Undiksha, 1(1).

Lindawati, F., Siska D., \& Maftukhin, A. (2013). Penerapan model pembelajaran project based learning untuk meningkatkan kreativitas siswa MAN I Kebumen. Jurnal Radiasi, Vol. 3, (1). Hlm. 42-45.

Mediawati, E. (2011). Pembelajaran akuntansi keuangan melalui media komik untuk meningkatkan prestasi mahasiswa. Jurnal penelitian pendidikan, 12(1), 68-76.

Nurohman, S. (2007). Pendekatan project based learning sebagai upaya internalisasi scientific method bagi mahasiswa calon guru fisika.

Purnomo, E. A., \& Mawarsari, V. D. (2014). Peningkatan kemampuan pemecahan masalah melalui model pembelajaran ideal problem solving berbasis project based learning. Jurnal Karya Pendidikan Matematika, 1(1).

Rais, M. (2010). Project based learning: inovasi pembelajaran yang berorientasi soft skills. Makalah dalam Seminar Nasional Pendidikan Teknologi dan Kejuruan Fakultas Teknik Universitas Negeri Surabaya 11 Desember 2010. 
Sani, Ridwan Abdullah. (2013). Inovasi Pembelajaran. Jakarta : Bumi Aksara.

Susilo, A. B. (2012). Pengembangan model pembelajaran IPA berbasis masalah untuk meningkatkan motivasi belajar dan berpikir kritis siswa SMP. Journal of Primary Education, 1(1).

Septiasih, N. W. A., Japa, I. G. N., \& Arini, N. W. (2016). Penerapan Project Based Learning Berbantuan Video Untuk Meningkatkan Aktivitas dan Hasil Belajar IPA di SD. MIMBAR PGSD Undiksha, 4(1).

Schunk, D. H. (2012). Learning Theories An Aducation Perspective Teori-teori Pembelajaran: Prespektif Pendidikan. Yogyakarta: Pustaka Pelajar

Saputra, D. I., Abdullah, A. G., \& Hakim, D. L. (2013). Pengembangan Model Evaluasi Pembelajaran Project Based Learning Berbasis Logika Fuzzy. Innovation of Vocational Technology Education, 9(1).Tampubolon, S. (2014). Penellitian Tindakan Kelas SEBAGAI PENGEMBANGAN PROFESI DAN KEILMUAN:Jakarta:Penertbit Erlangga

Umi, U. (2015). Penerapan pendekatan saintifik melalui model project based learning untuk meningkatkan ketrampilan proses dan hasil belajar siswa kelas IV SD negeri seworan, Wonosegoro. Scholaria: Jurnal Pendidikan dan Kebudayaan, 5(1), 24-38.

Wajdi, Fathullah. (2017). Implementasi Project Based Learning (PBL) dan Penilaian Autentik dalam Pembelajaran Drama Indonesia. Jurnal Pendidikan Bahasa dan Sastra, Vol. 17, No. 1, April 2017, Hal. 81-97.

Winanto, A., \& Makahube, D. (2016). Implementasi Strategi Pembelajaran Inkuiri Untuk Meningkatkan Motivasi Dan Hasil Belajar Ipa Siswa Kelas 5 Sd Negeri Kutowinangun 11 Kota Salatiga. Scholaria: Jurnal Pendidikan Dan Kebudayaan, 6(2), 119-138.

Wibowo, D. (2015). Motivasi Berprestasi dalam Kaitannya dengan Kinerja Guru. Scholaria: Jurnal Pendidikan Dan Kebudayaan, 5(3), 65-74.

Yance, R. D. (2013). Pengaruh penerapan model project based learning (PBL) terhadap hasil belajar fisika siswa kelas XI IPA SMA Negeri 1 Batipuh Kabupaten Tanah Datar. Pillar of Physics Education, 1(1). 